JELENA LUKIĆ ${ }^{*}$

UDC 658.5:004

Scientific review paper

\title{
THE IMPACT OF INFORMATION AND COMMUNICATION TECHNOLOGY ON DECISION MAKING PROCESS IN THE BIG DATA ERA
}

The information necessary to make important decisions is held by many different hierarchical levels in organizations and management needs to find the answer on the question should the decisions be centralized and made by the top management or decentralized and made by the managers and employees of the lower-level units. This question becomes more important in the big data era which is characterized by volume, velocity, and variety of data.

The aim of this paper is to analyze whether information and communication technology leads to centralization or decentralization tendencies in organizations and to give answer on the question what are the new challenges of decision making process in the big data era.

The conclusion is that information and communication technology provides all organizational level with information that traditionally was used by only few levels, reducing internal coordination costs and enabling organizations to allow decision making across a higher range of hierarchical levels. But final decision of allocation of decision rights depends on knowledge of employees, especially in the big data era, where professionals with new knowledge and skills (known as data scientist) became of tremendous importance.

Key words: information and communication technology, decision making, centralization, decentralization, big data

\section{Introduction}

Use of information and communication technology (ICT) leads to a change in specification of decision rights, reward systems and performance-evaluation system (see Figure 1) which Brickley, Smith and Zimmerman collectively term organizational architecture. Three-legged stool emphasizes the importance of balance and alignment of these variables which are predicted to jointly interact to affect organizational performance. If one of these variables changes, the remaining two also have to change in order to keep the required balance and not to deteriorate organizational performance. ${ }^{1}$

Jelena Lukić, MSc, Parallel d.o.o., Belgrade, e-mail: jelena.jl.lukic@gmail.com

1 Brickley J., Zimmerman J., Smith C.: Managerial Economics and Organizational Architecture, McGraw-Hill companies, Irwin 2007. 
Figure 1: Organizational architecture

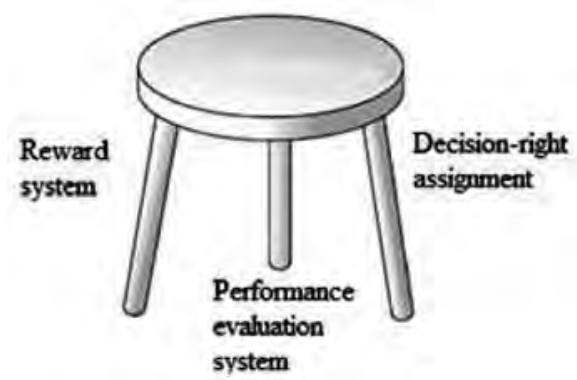

Source: Brickley J., Zimmerman J., Smith C.: Managerial Economics and Organizational Architecture, McGraw-Hill companies, Irwin 2007.

The aim of this paper is to examine the impact of information and communication technology on decision-rights assignment, as one of the three component of organizational architecture. The information necessary to make important decisions is held by many different employees and management of organizations needs to be aware that no one in organization knows everything. The successes and failures of many organizations depend more on knowledge and according to many scientists, organizational knowledge is the ultimate source of competitive advantages. ${ }^{2}$ A major challenge facing business organization is to make effective use of the knowledge in decision making. Decision making is one of the key processes in organizations and a basic task of management at all levels, it is "a process of identifying a problem, evaluating alternatives, and selecting one alternative". ${ }^{3}$ The real challenge for organizations is to find the answer on the question should the decision rights be centralized and made by the top management or should be decentralized and made by the managers of the lower-level units. Leavitt and Whisler were the first authors who predicted that the introduction of IT in organizations would lead to centralization of decision making. ${ }^{4}$ Over all this years, many studies have attempted to analyze this issue and give the right answer on whether or not ICT leads to centralization or decentralization. ${ }^{5}$ But is there only one right solution? This paper will try to answer on the following questions: 1) Does ICT lead to centralization or decentralization of decision rights; 2 ) What are the new challenges of decision making process in the big data era?

2 Nonaka Ikujiro, Takeuchi Hirotaka: The Knowledge-Creating Company: How Japanese Companies Create the Dynamics of Innovation, Oxford University Press, USA 1995.

3 Cole A. Gerald: Management theory and practice, Thomson, London 2004, 151.

4 Leavitt J. Harold, Whisler L. Thomas: “Management in the 1980's “, Harvard Business Review, November-December/1958.

5 Huber P. George: "A Theory of the Effects of Advanced Information Technologies on Organizational Design, Intelligence, and Decision Making“, The Academy of Management Review, Vol. 15, No. 1, pp. 47-71/1990. 


\section{Centralization versus decentralization of decision making}

One of the key characteristics of each organization is whether its decision making policies are centralized or decentralized. Organization is centralized when decision making is kept at the top level of the organization, but opposite, when decisions are delegated to lower organizational levels it is decentralized. ${ }^{6}$ To centralize or to decentralize is the key question for many organizations.

In centralized organizations, policies and procedures need to be approved by top level managers, and they make all the decisions. On the one hand this allows the entire organization to use the same resources and thus create process efficiency, ${ }^{7}$ but on the other hand centralization does not allow employees to implement their own decisions without approval from higher levels in organizations which might be time consuming. Key benefit of decentralization is that it empowers employees to solve their own problems, create their own practices which are the best at that given moment making them intrinsically motivated, and top management has more time to make other, strategic decisions.

Table 1: Advantages of centralization and decentralization

\begin{tabular}{|l|l|}
\hline \multicolumn{1}{|c|}{ ADVANTAGES OF CENTRALIZATION } & ADVANTAGES OF DECENTRALIZATION \\
\hline - The easier implementation of a common policy & - Enables decisions to be made closer to the \\
for the organization; & operational level of word; \\
- Providing a consistent strategy across the & $\begin{array}{l}\text { Increased responsiveness to local } \\
\text { circumstances; }\end{array}$ \\
organizations; & - Improved level of personal customer service; \\
- Preventing sub-units becoming too & - More in keeping with developments in flatter \\
- Making easier coordination and & and more flexible structures; \\
control; & - Support services are more likely to be effective; \\
- Improved economies of scale and a reduction in & - Provides opportunities for training and \\
overhead costs; & development in management; \\
- Greater use of specialization, including better & - Usually it has an encouraging effect on the \\
facilities and equipment; & motivation and morale of staff. \\
- Improved decision-making which might & \\
otherwise be slower. & \\
\hline
\end{tabular}

Source: Mullins J. Laurie: Management and organizational behavior, Prentice Hall, Harlow 2005, 607 .

Beside the presented advantages (see Table 1), there are some treats regarding to decentralization. It may create some of the problems like duplication of

6 Daft Richard: Organization Theory and Design, Cengage Learning, United States 2010.

7 Dewett Todd, Gareth R. Jones: "The role of information technology in the organization: a reviw, model and assessment", Journal of Management, No. 27, pp. 313-346 / 2001. 
activities and inconsistency of decisions. ${ }^{8}$ It is very hard to give one clear answer on centralization versus decentralization, because they may produce different but desired outcomes - decentralized organization lead to product design and incremental innovation, but centralized organization produce major technological advances. ${ }^{9}$

\section{ICT impact on trade-off: centralization versus decentralization}

In decision making process, development, evaluation and selection of alternatives would benefit from exchanges of information among employees ${ }^{10}$ which may be time consuming and in some cases require a great effort. ICT, compared with traditional communication that was placed in the relation superior-subordinate, strengthens the intensity and flow of information within the organization in all directions, vertically, horizontally and laterally. ${ }^{11}$ By rapid increase in the quantity of information and the speed of their transfer from one location to another, ICT significantly reduced communication costs, ${ }^{12}$ and effort required from employees who are separated in different functional units. ${ }^{13}$

A product developer sent a message to distribution lists that reach thousands of people asking for suggestions about how to add a particular new product feature. Within two weeks, he had received over 150 messages in reply, cutting across geographical, departmental, divisional, and hierarchical boundaries, almost all from people the product developer even did not know.

From abovementioned example we may conclude that ICT has benefited in at least two ways: 1) It has enabled participation of customers and clients from each part of the world in product development which further lead to customization according to their needs and desires; 2) It has increased a number of par-

8 Dunford Richard, Palmer Ian: "Coexistence of old and new organizational practices: Transitory phenomenon or enduring feature", Asia Pacific Journal of Human Resources, Vol. 45, No. 1, pp. 24-43/2007.

9 DeSanctis G., Glass J., Ensing I.: "Organizational design for R\&D”, Academy of Management Executive, Vol. 16, No. 3, pp. 55-66/2002.

10 Huber P. George

11 Hiltz, S. R., Johnson, K., Turoff, M.: The virtual classroom: learning without limits via computer networks, Ablex, Norwood 1986.

12 Henderson, J., Venkatraman, N.: "Strategic alignment: Leveraging information technology for transforming organizations”, IBM system journal, Vol. 32, No. 1, pp. 472-484/1993.

13 Hiltz, S. R., \& Turoff, M.: The network nation: Human communication via computer, Addison- Wesley, New York 1978.

14 Sproull, L., Keisler, S.: "Reducing social context cues: Electronic mail in organizational communication", Management Science, 32/1986, 1510. 
ticipants, the speed of collecting the information, and decreased the costs of communication.

With quickly and accurately information available through ICT, top managers may make decisions, especially when there is a lack of confidence in lower level employees and concern that information about entire organizational situation and policies will not be use appropriately. ${ }^{15}$ Information is more simply and faster available, the top management is less dependent on middle-managers and reduces its number. ${ }^{16}$ Consequently, ICT makes the allocation of decision rights centralized in the top management. ${ }^{17}$ But, simultaneously, ICT enables lower level employees to be better informed about organizational policies and situations, priorities which impact on decisions to be globally optimal. ${ }^{18}$ ICT employees and lower level managers gain access to information which was reserved to the principal, ${ }^{19}$ and they are enabled to make decisions independently, motivated for higher effort because of intrinsic motivation. Principal has the ability to monitor agents indirectly via computer, which implies that he can delegate decisions but he is also able to control the agent. This control is known as digital Taylorism because it sometimes causes pressure and stress for employees who are monitored vie e-mail, telephone calls, computer files, Internet logs. ${ }^{20}$

We can conclude that ICT provide all organizational levels with information that traditionally was used by only one level, enabling organizations to allow decision making across a greater range of hierarchical levels.

\section{The impact of ICT on internal coordination costs}

Where is the optimal degree of centralization within one organization? To what extent should lower level managers be given the authority to act independently of higher level management? In most cases, the interests of the principal and the manager are not perfectly aligned; the manager can use his informational advantage to make choices that are not in the best interest of the principal. ${ }^{21}$

15 Huber, G., McDaniel, R.: "Exploiting information technology to design more effective organizations”, 221-236, in: Jarke M. (ed.): Managers, micros, and mainframes, Wiley, New York 1986.

16 Drucker Peter: "The Coming of the New Organization", Harvard Business Review, January-February/1988.

17 Leavitt J. Harold, Whisler L. Thomas

18 Huber P. George

19 Dewett Todd, Gareth R. Jones

20 Stanford, N.: Organization Design: The Collaborative Approach, Elsevier ButterworthHeinemann, Oxford 2005.

21 Aghion Philippe, Tirole Jean: "Formal and real authority in organizations", Journal of Political Economy, Vol. 105, No. 1, pp. 1-29/1997. 
In making the decision on the optimal location of decision rights, an organization is faced with a trade-off between agency costs and knowledge transfer costs (see Table 2). Agency costs consist of monitoring costs, bonding costs and residual costs, while decision information costs consist of information processing costs (for communication and documentation) and opportunity costs resulting from poor information. ${ }^{22}$

Table 2: Internal Coordination Costs

\begin{tabular}{|c|c|c|}
\hline INTERNAL & AGENCY COSTS & $\begin{array}{l}\text { - Monitoring Costs } \\
\text { - Bonding Costs } \\
\text { - Residual Loss }\end{array}$ \\
\hline $\begin{array}{c}\text { COORDINATION } \\
\text { COSTS }\end{array}$ & $\begin{array}{c}\text { KNOWLEDGE } \\
\text { TRANSFER COSTS }\end{array}$ & $\begin{array}{l}\text { - Information Processing Costs } \\
\text { - Communication } \\
\text { - Documentation } \\
\text { - Opportunity costs due to poor information }\end{array}$ \\
\hline
\end{tabular}

Source: Adapted from Gurbaxani V., Whang S.: "The Impact of Information Systems on Organizations and Markets", Communications of the ACM, Vol. 34, No. 1, pp. 60-73/1991, 62 .

A major challenge facing business organization is to make effective use of the knowledge in decision making. The success and failure of many organizations depends more on knowledge and according to many scientists, organizational knowledge is the ultimate source of competitive advantage. ${ }^{23}$

F. Hayek was an early proponent of the importance of knowledge for organization performance in terms of colocation of decision-making authority with the knowledge important to those decisions. He argues that distribution of knowledge leads to decentralization:

„...decisions must be left to the people who are familiar with particular circumstances of time and place, who know directly of the relevant changes and of the resources immediately available to meet them. We cannot expect that this problem will be solved by first communication all this knowledge to a central board which, after integrating all knowledge, issues its orders. We must solve it by some form of decentralization." 24

ICT decreases knowledge transfer costs and thus foster centralization, because it is possible for the principal to monitor managers and to coordinate activities by low costs. The use of ICT leads to overall reduction of knowledge

22 Gurbaxani V., Whang S.: “The Impact of Information Systems on Organizations and Markets", Communications of the ACM, Vol. 34, No. 1, pp. 60-73/1991.

23 Nonaka Ikujiro, Takeuchi Hirotaka

24 Hayek, F.A.: “The Use of Knowledge in Society”, Economica, Vol. 35, No. 4, pp. 519$530 / 1945,524$. 
transfer costs, and the degree of delegation of decision rights should be located where the sum of these costs is minimized..$^{25}$

\section{Big Data: characteristics and changing role of decision making}

Increasing volumes of data measured with exabytes and zettabytes, from a tremendous variety of sources and at hastening speed will impose new challenges for organizations. These trends are known as Big Data, and can be described by $4 \mathrm{~V}:{ }^{26} 1$ ) Volume (huge amount of data), 2) Variety (data from social networks, data from digital TV, credit cards, medical devices, sensors, bar codes, surveillance cameras, etc.), 3) Velocity (the speed of collecting and converting data into value), 4) Value (creating value of collected data). By using Big Data concept these data can be digitalized, analyzed and stored in real time, ${ }^{27}$ forming the basis for decision making.

According to McKinsey Institute research, creating value by applying Big Data is generated on the basis of: ${ }^{28} 1$ ) the transparency of data, 2) data analysis and experimentation to discover needs, expose variability and improve performance, 3) segmenting populations to customize actions, 4) replacing/supporting human decision making with automated algorithms, 5) innovating new business models, products and services.

Implementation of new information systems to collect and analyze data is just one, the first step, but organizations will also have to make changes in their processes in order to take all potential of new data inputs (see Table 3). ${ }^{29}$ Big Data creates possibility for different type of decision making, putting itself as a valuable resource like talent and money. ${ }^{30}$ In the big data era, organizations are focused to data analysis and real time decision-making based on tremendous amount of information ${ }^{31}$ which caused many changes in assignment of decision rights. It leads to data-driven decision making at both - the strategic and operational levels, empowering employees to make decisions which traditionally belongs to 25 Gurbaxani V., Whang S.

26 Manyika James et al.: "Big data: The next frontier for innovation, competition, and productivity”, McKinsey Global Institute 2011, http://www.mckinsey.com/insights/business_technology/big_data_the_next_frontier_for_innovation (16.04.2014.)

27 Galbraith Jay: “Organizational Design Challenges Resulting From Big Data”, Journal of Organization Design, Vol. 3, No. 1, pp. 2-13/2014.

28 Manyika James et al., 5

29 A report from the Economist Inelligence Unit: "In search of insight and foresight -Getting more out of bit data", 2013, http://www.oracle.com/us/solutions/ent-performance-bi/ business-intelligence/eiu-oracle-insights-1930398.pdf (15.04.2014.)

30 Galbraith Jay, 2014.

31 Chen H, Chiang RHL, Storey VC.: "Business intelligence and analytics: From big data to big impact”, MIS Quarterly, Vol. 36, No. 4, pp. 1165-1188/2012. 
upper levels ${ }^{32}$, self-control of employees as they feel that they are under constant control because all information are visible for others. ${ }^{33}$

Table 3: Comparison of Past and Future Information Visibility

\begin{tabular}{|l|l|}
\hline \multicolumn{1}{|c|}{ Smart Machine Era } & \multicolumn{1}{c|}{ Big Data Era } \\
\hline - Historical data & - Real-time data \\
- Self-created, high-quality datasets & - Large amount of data including unreliable \\
- Strategic level & external datasets \\
- Experience-driven decision making & - Strategic and operational levels \\
& - Data-driven decision making \\
\hline
\end{tabular}

Source: Adapted from Berner Martin, Graupner Enrico, Maedche Alexander: "The Information Panopticon in the Big Data Era", Journal of Organization Design, Vol. 3, No. 1, pp. 14-19/2014, 15.

With tremendous amount of data now available, companies in almost every industry are focused on exploiting data for competitive advantage. With controlled experiments, companies can test hypotheses and analyze results to guide decisions and operational changes. ${ }^{34}$ But, they need to acquire new type of resource for real-time decision making - professionals which can make value with the big data, which are called data scientists, digital and analytics experts, ${ }^{35}$ information strategists, information systems professionals, data governance and ethics professionals. ${ }^{36}$

Among all advantages, data-driven decision making imposes some new challenges. While scholars in the field of ICT claim that the main function of ICT in the big data is to provide accurate information for decision making, ${ }^{37}$ other scholars advocate strongly for the importance of intuition for complex problem solving which is often neglected. ${ }^{38}$ Regarding the type of decisions,

$32 \quad$ Berner Martin, Graupner Enrico, Maedche Alexander: "The Information Panopticon in the Big Data Era”, Journal of Organization Design, Vol. 3, No. 1, pp. 14-19/2014.

33 Zuboff Shoshana: In the Age of Smart Machine: The Future of Work and Power, Basic Books, New York 1988.

34 Brown Brad, Chui Michael, Manyika James: “Are you ready for the era of „big data“?" McKinsey Quarterly, 2012, http://www.mckinsey.com/insights/strategy/are_you_ready_ for_the_era_of_big_data (06.04.2014.)

35 Galbraith Jay, 2014.

36 Miller Steven: "Collaborative Approaches Needed to Close the Big Data Skills Gap", Journal of Organization Design, Vol. 3, No. 1, pp. 26-30/2014.

37 Davenport H. Thomas: "BI and organizational decisions", International Journal of Business Intelligence Research, Vol. 1, No. 1, pp. 1-12/2010.

38 Hammond R. Kenneth et al.: "Direct comparison of the efficacy of intuitive and analytical cognition in expert judgment", IEEE Transactions on Systems, Man, and Cybernetics, Vol. SMC-17, No. 5, pp. 753-770/1987. 
data-driven decision making seems to be better at operational or tactical level since data make it easy to automate routine tasks and decisions. Strategic decisions still require intuition and judgment of decision makers, but armed with the right data at the right time which forms the basis for decision making. ${ }^{39}$

As Galbraith suggested, Big Data will be the fifth dimension of organizational design ${ }^{40}$ because modern organizations concatenate one more function beside traditional functions in the big data era - analytics function. Again, question to centralize or to decentralize is in front of the management. The key question is how to organize and where to locate the analytics function which purpose is "to extract value from data, create and distribute reports, build and deploy statistical and data-mining models, explore and visualize data, etc" ${ }^{41}$

There are three basic models for locating the analytics function within the organization: ${ }^{42}$

1) Centralized analytics where data scientist are placed in a single unit. This model is very easy for achieving critical mass, gathering and analyzing necessary data, but data scientists may be far away from the business units they are supposed to support.

2) Decentralized analytics where the groups of data scientists are placed in each business unit in organization. This approach makes it easier for data scientists to collaborate with their respective business units, but it is difficult to achieve critical mass on enterprise-wide problems and opportunities.

3) Hybrid aprroach in which a critical mass of data scientists is placed in a central unit, and the remaining data scientists are distributed throughout the organization.

None of the presented models provides a perfect organizational solution, each model has both advantages and disadvantages. Even in the big data era, beside all data that organizations have, they are faced with new challenge: where to locate the new analytics function which is the new source of competitive advantage in the big data era.

39 Chongqi Wu: "How to use big data to make better business decisions", 2013, http://www. sbnonline.com/component/k2/13-national-editions/26203\#.U0Pey_mSxjY (10.04.2014.)

40 Galbraith Jay: "The evolution of enterprise organization designs", Journal of Organization Design, Vol. 1, No. 2, Pp 1-13/2012.

41 Grossman L. Robert, Siegel P. Kevin: “Organizational Model for Big Data and Analytics“, Journal of Organization Design, Vol. 3, No. 1, pp. 20-25/2014, 20.

42 Ibid, 22

Vol. 11, No 2, 2014: 221-234 


\section{Conclusion}

The aim of this paper was to analyze whether information and communication technology leads to centralization or decentralization tendencies in organizations and to give answer on the question what are the new challenges of decision making process in the big data era.

ICT with its characteristics and potential benefits has a two-way impact on the allocation of decision rights. On the one hand, ICT leads to decentralization because it enables lower organizational levels to be better informed about organizational policies and goals, while at the same time top management has the ability to monitor all made decisions. On the other hand, ICT can lead to centralization giving the top management all necessary information in real time. In general, ICT provide all organizational levels with information that traditionally was used by only one or few levels, enabling organizations to allow decision making across a greater range of hierarchical levels.

Big data era, characterized by volume, velocity, and variety of data brings new challenges for decision making process. Organizations beside ICT infrastructure need professionals with new skills and knowledge for data-driven decision making and they are faced with challenge where to locate the new function - analytics function.

\section{Literature}

- Aghion Philippe, Tirole Jean (1997): "Formal and real authority in organizations", Journal of Political Economy, Vol. 105, No. 1, pp. 1-29.

- Berner Martin, Graupner Enrico, Maedche Alexander (2014): “The Information Panopticon in the Big Data Era", Journal of Organization Design, Vol. 3, No. 1, pp. 14-19.

- Brickley J., Zimmerman J., Smith C. (2007): Managerial Economics and Organizational Architecture, McGraw-Hill, Irwin.

- Brown Brad, Chui Michael, Manyika James (2012): "Are you ready for the era of „big data“?" McKinsey Quarterly, http://www.mckinsey.com/insights/strategy/are_you_ready_for_the_era_of_big_data (06.04.2014.)

- Cole A. Gerald (2004): Management theory and practice, Thomson, London.

- Chongqi Wu (2013): "How to use big data to make better business decisions", http://www.sbnonline.com/component/k2/13-national-editions/26203\#. U0Pey_mSxjY (10.04.2014.)

- Daft Richard (2010): Organization Theory and Design, Cengage Learning, United States.

- Davenport H. Thomas (2010): "BI and organizational decisions", International Journal of Business Intelligence Research, Vol. 1, No. 1, pp. 1-12. 
- Dewett Todd, Gareth R. Jones (2001): "The role of information technology in the organization: a reviw, model and assessment", Journal of Management, No. 27, pp. 313-346.

- DeSanctis G., Glass J., Ensing I. (2002): “Organizational design for R\&D”, Academy of Management Executive, Vol. 16, No. 3, pp. 55-66.

- Dunford Richard, Palmer Ian (2007): "Coexistence of old and new organizational practices: Transitory phenomenon or enduring feature", Asia Pacific Journal of Human Resources, Vol. 45, No. 1, pp. 24-43.

- Drucker Peter (1988): “The Coming of the New Organization“, Harvard Business Review, January-February.

- Galbraith Jay (2012): "The evolution of enterprise organization designs", Journal of Organization Design, Vol. 1, No. 2, pp 1-13.

- Galbraith Jay (2014): “Organizational Design Challenges Resulting From Big Data”, Journal of Organization Design, Vol. 3, No. 1, pp. 2-13.

- Gurbaxani V., Whang S. (1991): “The Impact of Information Systems on Organizations and Markets", Communications of the ACM, Vol. 34, No. 1, pp. 60-73.

- Grossman L. Robert, Siegel P. Kevin (2014): "Organizational Model for Big Data and Analytics", Journal of Organization Design, Vol. 3, No. 1, pp. 20-25.

- Hammond R. Kenneth et al. (1987): "Direct comparison of the efficacy of intuitive and analytical cognition in expert judgment", IEEE Transactions on Systems, Man, and Cybernetics, Vol. SMC-17, No. 5, pp. 753-770.

- Hayek, F.A. (1945): “The Use of Knowledge in Society", Economica, Vol. 35, No. 4, pp. 519-530.

- Huber P. George (1990): "A Theory of the Effects of Advanced Information Technologies on Organizational Design, Intelligence, and Decision Making", The Academy of Management Review, Vol. 15, No. 1, pp. 47-71.

- Huber, G., McDaniel, R. (1986): "Exploiting Information technology to design more effective organizations”, 221-236, in: Jarke M. (ed.): Managers, micros, and mainframes, Wiley, New York.

- Hiltz, S. R., Johnson, K., Turoff, M. (1986): The virtual classroom: learning without limits via computer networks, Ablex, Norwood.

- Hiltz, S. R., \& Turoff, M. (1978): The network nation: Human communication via computer, Addison- Wesley, New York.

- Henderson, J., Venkatraman, N. (1993): "Strategic alignment: Leveraging information technology for transforming organizations", IBM system journal, Vol. 32, No. 1, pp. 472-484.

- Leavitt J. Harold, Whisler L. Thomas (1958): "Management in the 1980's", Harvard Business Review, November-December. 
- Nonaka Ikujiro, Takeuchi Hirotaka (1995): The Knowledge-Creating Company: How Japanese Companies Create the Dynamics of Innovation, Oxford University Press, USA.

- Miller Steven (2014): "Collaborative Approaches Needed to Close the Big Data Skills Gap", Journal of Organization Design, Vol. 3, No. 1, pp. 26-30.

- Mullins J. Laurie (2005): Management and organisational behaviour, Prentice Hall, Harlow.

- $\quad$ Sproull, L., Keisler, S. (1986): "Reducing social context cues: Electronic mail in organizational communication", Management Science, 32.

- Stanford, N. (2005): Organization Desing: The Collaborative Approach, Elsevier Butterworth-Heinemann, Oxford. 
Lukić Jelena, master

Parallel d.o.o. Beograd

\title{
UTICAJ INFORMACIONO-KOMUNIKACIONE TEHNOLOGIJE NA PROCES DONOŠENJA ODLUKA U ERI VELIKIH PODATAKA
}

\author{
S a ž e $\mathbf{t}$ a $k$
}

Stalno rastuća brzina, količina i raspoloživi izvori podataka kao i mogućnost njihovog prikupljanja, obrade i analize uslovili su pojavu nove ere - ere velikih podataka. Kroz istoriju, da bi neka organizacija uspešno funkcionisala, bilo je bitno da uspostavi adekvatan mehanizam za proces odlučivanja. U eri velikih podataka, menadžment organizacija, više nego ikada, biva suočen sa izazovom da li prava za donošenje odluka treba da budu koncentrisana na vrhu i rezervisana za top menadžment ili trebaju biti decentralizovana na menadžere nižih organizacionih delova, obzirom na činjenicu da podaci mogu biti značajan izvor konkurentske prednosti ukoliko se primene na pravi način. Cilj ovog rada bio je da ukaže da li primena informaciono-komunikacionih tehnologija u organizaciji utiče na veći stepen centralizacije ili decentralizacije prava za donošenja odluka i da identifikuje izazove koje pred menadžment organizacija stavlja era velikih podataka u procesu donošenja odluka. Kao zaključak se nametnula činjenica da informaciono-komunikaciona tehnologija (IKT) svim svojim karakteristikama i potencijalnim prednostima deluje dvojako na alokaciju prava za donošenje odluka. Sa jedne strane, IKT omogućava decentralizaciju jer pruža pristup informacijama i podacima u okviru svih organizacionih delova, obezbeđuje da svi budu upoznati sa pravilima i procedurama organizacije, ali i osigurava da donosioci odluka budu pod kontrolom i konstantnim nadgledanjem od strane nadređenih, usled čega se stvaraju uslovi za donošenje odluka koje su u interesu cele organizacije. Sa druge strane, IKT može podstaći i centralizaciju jer top menadžment ima na raspolaganju sve neophodne informacije u realnom vremenu što predstavlja ključni input za proces donošenja odluka, posebno u slučaju kada postoji nepoverenje u podređene i briga da donete odluke neće biti u interesu cele organizacije. Odluke o alokaciji prava za donošenje odluka donose se ne samo na osnovu raspoloživosti informacija, već i na osnovu znanja i sposobnosti zaposlenih, posebno u eri velikih podataka kada dolazi do izražaja značaj zaposlenih koji poseduju interdisciplinarna znanja i veštine. Era velikih podataka je dovela do novih koncepata odlučivanja, među kojima je i odlučivanje koje je zasnovano i vođeno kvantitativnim podacima. Međutim, ovakvom vidu odlučivanja se često kao nedostatak pripisuje zanemarivanje intuicije. Takođe, pored svih svojih prednosti, era velikih podataka suočava menadžment organizacija sa brojnim izazovima i dilemama među kojima je i pitanje na koji način organizovati analitičku funkciju koja se javlja kao nova funkcija u savremenim organizacijama.

Ključne reči: informaciono-komunikaciona tehnologija, donošenje odluka, centralizacija, decentralizacija, era velikih podataka

Vol. 11, No 2, 2014: 221-234 
